\title{
AUGMENTED REALITY SEBAGAI MEDIA PEMBELAJARAN INOVATIF DI ERA REVOLUSI INDUSTRI 4.0
}

\author{
Yeka Hendriyani $^{1}$, Hansi Effendi ${ }^{2}$, Dony Novaliendry ${ }^{3}$, Hastria Effendi ${ }^{4}$ \\ ${ }^{1,3}$ Jurusan Teknik Elektronika, Fakultas Teknik, UNP \\ ${ }^{2}$ Jurusan Teknik Elektro, Fakultas Teknik, UNP \\ ${ }^{4}$ Jurusan Kesehatan dan Rekriasi, Fakultas Ilmu Keolahragaan, UNP \\ e-mail: yekahendriyani@ft.unp.ac.id, hans_79@ft.unp.ac.id, donynovaliendry@ft.unp.ac.id
}

\begin{abstract}
The main purpose of this paper is to uncover the results of a survey study regarding teacher opinions on the use of Augmented Reality (AR) in learning. For this purpose, marker-based cellular augmented reality applications have been developed and computer hardware is used as training material. In addition, teachers are given training for four days to get to know the basics of augmented reality technology, the software used, the environment to create marker-based AR objects. The data was collected through surveys and open-ended questions on teachers who are members of the English MGMP Kab. 50 cities. The tools and technology needed to develop AR and development experience are also shared. According to the survey results teachers are very enthusiastic about using augmented reality in their learning. The result of this article is the perception of the use of Augmented Reality technology for the development of instructional media by English teachers in the positive category.
\end{abstract}

Keyword: Augmented Reality, Vuforia, Unity 3D, MGMP English

\section{INTISARI}

Tujuan utama dari makalah ini adalah untuk mengungkap hasil studi survei mengenai pendapat guru tentang penggunaan Augmented Reality (AR) dalam pembelajaran. Untuk tujuan ini, aplikasi augmented reality seluler berbasis marker telah dikembangkan dan perangkat keras komputer digunakan sebagai bahan pelatihan. Selain itu, guru diberi pelatihan selama empat hari untuk mengenal dasar-dasar teknologi augmented reality, software yang digunakan, environment sampai membuat objek AR berbasis marker. Pengumpulan data dilakukan secara survey dan pertanyaan terbuka terhadap guru-guru yang tergabung dalam MGMP Bahasa Inggris Kab. 50 Kota. Alat dan teknologi yang dibutuhkan untuk mengembangkan AR dan pengalaman pengembangan juga dibagikan. Menurut hasil survei guru sangat antusias menggunakan augmented reality dalam pembelajaran mereka. Hasil dari artikel ini adalah persepsi penggunaan teknologi Augmented Reality untuk pengembangan media pembelajaran oleh guru Bahasa Inggris berada pada kategori positif.

Kata Kunci: Augmented Reality, Vuforia, Unity, MGMP Bahasa Inggris.

\section{PENDAHULUAN}

Penggunaan teknologi informasi dan komunikasi (TIK) dalam pendidikan dan pelatihan kegiatan terus meningkat dari hari ke hari. Sistem pendidikan telah terpasang pentingnya menggunakan TIK dalam pembelajaran, dan banyak upaya telah dilakukan untuk menyediakan peralatan dan teknologi pengajaran interaktif di sekolah. Baru-baru ini, salah satu yang terbesar kesempatan adalah augmented reality. Kemungkinan baru untuk pengajaran dan pembelajaran disediakan oleh augmented reality semakin diakui oleh para peneliti pendidikan.

Augmented Reality adalah teknologi yang menawarkan pendekatan pendidikan baru di Indonesia membantu peserta didik mengembangkan kapasitas kritis dan pemahaman konsep yang lebih dalam investigasi ilmiah yang mendasarinya. Juga, augmented reality memungkinkan untuk belajar konsep abstrak seperti bentuk tiga dimensi dan objek geometri, 
yaitu sulit dipahami melalui buku teks. Karena augmented reality menggabungkan digital apa pun informasi dalam pengaturan dunia nyata, yaitu data atau informasi elektronik, dalam berbagai ormat media tidak hanya sebagai media visual dan grafik tetapi juga teks, audio, video dan hamparan haptic, memiliki potensi penelitian besar pada pengaturan pendidikan.

Augmented reality membawa kemungkinan yang benar-benar tidak terbatas untuk proses belajar mengajar. Sementara augmented reality sistem sering dikaitkan dengan pembelajaran informal, studi mengeksplorasi dampaknya di pendidikan formal, baik di sekolah dasar dan menengah [1]. Membangun dan menggunakan adegan augmented reality menggabungkan masalah kompleks yang aktif pemecahan dan kerja tim untuk menciptakan pengalaman pendidikan yang menarik untuk mengajarkan sains, matematika atau keterampilan bahasa, dan penelitian telah menemukan bahwa kegiatan ini meningkatkan motivasi siswa, keterlibatan, dan keterlibatan [2]. Teknologi augmented reality memiliki kemampuan untuk membuat dalam model 3D apa pun yang mungkin sulit divisualisasikan di dalam kelas, di komputer, di pikiran siswa. Konten abstrak dalam model visual membantu siswa untuk mendapatkan pemahaman yang lebih dalam tentang topik pelajaran.

Oleh karena itu, penelitian ini bermaksud untuk membantu pembaca mendapatkan wawasan tentang (1) pendapat guru dalam mengembangankan media pembelajaran menggunakan augmented reality di dalam kelas, dan (2) berbagi pengalaman proses pengembangan augmented reality.

\section{PENDEKATAN PEMECAHAN MASALAH}

Augmented reality adalah teknologi yang telah digunakan di berbagai bidang termasuk dalam pendidikan. Augmented reality memiliki potensi besar dalam pendidikan, lebih khusus dalam pembelajaran. Menggunakan teknologi ini dengan alat yang relevan, siswa dapat belajar dan bahkan membangun konten dengan apa yang mereka pelajari atau pahami tentang sebuah subjek. Dalam literatur, ada banyak studi yang menekankan bagaimana augmented reality digunakan dalam bidang ilmu kesehatan [3], kartografi dan ilmu informasi geografis [4], arsitektur [5], Pelatihan Simulasi[6] . [7] Serio, Ibáñez, \& Kloos, (2013) dalam penelitian mereka menunjukkan hasil bahwasanya teknologi Augmented Reality memiliki dampak positif pada motivasi siswa sekolah menengah. Selain itu, digunakan juga model motivasi Keller ARCS untuk mengumpulkan informasi mengenai perhatian, relevansi, kepercayaan diri, dan faktor motivasi kepuasan. Faktor motivasi dari perhatian dan kepuasan dalam lingkungan belajar berbasis augmented reality dinilai lebih baik daripada yang diperoleh dalam lingkungan pembelajaran berbasis slide [7]. Studi lain membandingkan augmented reality dan antarmuka web untuk belajar elektromagnet. Dalam penelitian ini tingkat aliran yang lebih tinggi diamati pada siswa yang bekerja dengan augmented reality dan laporan evaluasi menunjukkan hasil pembelajaran yang lebih baik untuk pengguna antarmuka augmented reality [7]. Dalam pelajaran siswa dituntut memahami konsep yang kompleks, untuk memperoleh pengetahuan melalui observasi, dalam hal ini imitasi dan partisipasi augmented reality dapat digunakan secara efektif. Meskipun [8] tidak menemukan perbedaan signifikan yang diamati dalam skor tes anatomi realitas virtual, augmented reality dan kelompok 3D yang diajukan, mereka mengamati manfaat intrinsik seperti peningkatan ketertarikan dan keterlibatan siswa. Seiring perkembangan teknologi dari desktop ke platform pembelajaran augmented reality kenyataannya juga bergeser ke perangkat seluler. [9] mengusulkan ponsel sistem pembelajaran augmented reality untuk melakukan kegiatan pembelajaran berbasis inkuiri. Menurut hasil penelitian, siswa yang belajar dengan augmented reality berbasis pendekatan pembelajaran bergerak menunjukkan motivasi yang jauh lebih tinggi dalam perhatian, dimensi kepercayaan, dan relevansi daripada mereka yang belajar dengan konvensional pendekatan pembelajaran mobile berbasis inkuiri [9]. Di pendidikan matematika dan geometri Construct3D yang berbasis pada kolaborasi seluler sistem augmented reality digunakan. Menurut hasil studi Construct3D mudah belajar, mendorong eksperimen dengan konstruksi geometris dan meningkatkan spasial keterampilan [10]. Sebuah studi untuk mengkontekstualisasikan pembelajaran siswa SSI tentang penggunaan energi nuklir dan polusi radiasi di unit radiasi online menunjukkan bahwa persepsi siswa tentang aktivitas AR positif. Juga, hasil lain dari penelitian ini menunjukkan bahwa unit SSI ditingkatkan oleh augmented reality mobile dapat meningkatkan pembelajaran siswa konsep sains [11]. Sebuah studi tentang penggunaan augmented reality dan pengaruhnya terhadap beban kognitif dan prestasi belajar siswa menunjukkan bahwa beban kognitif menurun karena informasi abstrak menjadi konkret dalam buku cetak melalui multimedia bahan dalam aplikasi augmented reality seluler [12] Untuk 
mengembangkan aplikasi augmented reality, alat dan teknologi pertama yang ada harus dipertimbangkan dengan cermat. Ada banyak kerangka kerja dan platform yang dapat digunakan untuk itu mengembangkan aplikasi augmented reality. SDK dan kerangka kerja paling populer diberikan di bawah [13]:

- Vuforia : Vuforia adalah platform populer yang digunakan untuk bekerja dengan augmented reality pengembangan. Android, iOS dan Unity Editor didukung. Fitur yang didukung pengenalan berbagai jenis objek visual, teks, dan lingkungan pengakuan.

- EasyAR : EasyAR gratis dan mudah digunakan augmented reality SDK. Android, iOS, Windows, Mac dan Unity Editor didukung. Fitur yang didukung adalah objek 3D pengakuan, persepsi lingkungan, pengenalan cloud, solusi kaca cerdas, Aplikasi kemasan cloud.

- Wikitude : Wikitude adalah all-in-one augmented reality SDK. Android, iOS, Smart Kacamata didukung. Fitur yang didukung adalah pengenalan gambar, pelacakan 3D, GEO Data, Pengenalan cloud.

- ARToolKit : ARtoolKit adalah perpustakaan pelacakan sumber terbuka untuk augmented reality.

Android, iOS, Linux, Windows, Mac OS dan Smart Glasses didukung. Fitur yang didukung adalah posisi / orientasi kamera tunggal atau kamera tunggal pelacakan, plugin untuk Unity dan Open Scene Graph, kamera dan stereo optic kalibrasi.

\section{Metode}

Tujuan dari makalah ini adalah untuk mengeksplorasi pendapat calon guru tentang penggunaan augmented reality di ruang kelas dan berbagi langkah-langkah desain yang diikuti dalam mengembangkan materi augmented reality. Untuk tujuan ini, perangkat keras komputer dipilih sebagai bahan augmented reality.

\section{Desain Penelitian}

Dalam penelitian ini, desain penelitian yang digunakan adalah deskriptif. Desain penelitian deskriptif adalah metode yang valid untuk meneliti mata pelajaran tertentu dan sebagai studi pendahulu yang lebih kuantitatif. Penelitian deskriptif sering digunakan sebagai pra-kursor ke desain penelitian kuantitatif yang memberikan gambaran umum untuk beberapa petunjuk penting tentang variabel apa yang layak diuji secara kuantitatif Studi deskriptif berkaitan erat dengan studi observasional, tetapi tidak terbatas dengan metode pengumpulan data observasi. Studi kasus dan survei juga dapat ditentukan sebagai metode pengumpulan data yang digunakan dengan studi deskriptif [14]. Dalam desain penelitian deskriptif survei cross-sectional digunakan untuk mengambil snapshot dari frekuensi dan karakteristik pengalaman AR pada guru pada suatu waktu.

Metode penelitian yang digunakan yaitu metode penelitian survei untuk mengungkap bagaimana persepsi guru-guru terhadap penggunaan teknologi Augmented Reality dalam mengembangkan media pembelajaran. Kuesioner disebar kepada 21 guru MGMP Bahasa Inggris Kab. 50 Kota yang menjadi peserta dari kegiatan pelatihan pembuatan media pembelajaran berbasis Augmented Reality.

\section{HASIL DAN PEMBAHASAN}

\section{Proses pengembangan}

Aplikasi augmented reality berbasis marker telah dikembangkan dan perangkat keras komputer digunakan sebagai bahan ajar. Adapun tools yang digunakan adalah Vuforia SDK dan Unity yang memiliki dukungan dan dokumentasi yang baik. Unity adalah platform pengembangan game terbaik untuk membangun game 3D dan 2D berkualitas tinggi. Dalam penelitian ini, plugin Unity dengan Vuforia digunakan untuk mengembangkan materi augmented reality.

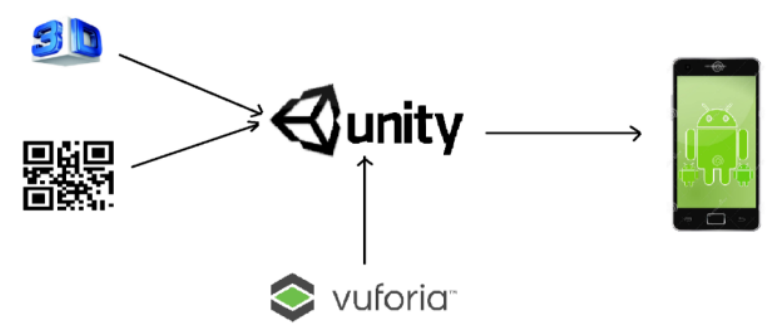

\section{Gambar 1. Proses Pengembangan Aplikasi Augmented Reality}

Model 3D: Objek virtual (dibuat oleh komputer yaitu video, teks atau model komputer 3D) adalah bagian kunci dalam aplikasi augmented reality. Kualitas dan fungsionalitas objek mempengaruhi kualitas aplikasi dan persepsi penggunaan masing-masing. Langkah pertama dalam desain augmented reality berbasis marker adalah mengembangkan model atau video $3 \mathrm{D}$, tautan yang dapat digunakan untuk menunjukkan ketika kamera memindai marker.

Kode QR: Kode QR adalah barcode matriks yang dapat dibaca oleh telepon pintar dan ponsel dengan kamera . Kode QR dapat dibuat dan dipindai oleh pembaca QR. Sebagian besar kode QR biasanya muncul sebagai kotak putih kecil dan bentuk 
geometris hitam. Mereka mampu mengkode informasi yang berkisar dari alamat web hingga tautan ke video YouTube, oleh karena itu dalam penggunaan pertama aplikasi; untuk mengunduh aplikasi dan pengaturan yang diperlukan dari Play Store, kode QR digunakan

Vuforia: Vuforia adalah ekstensi augmented reality yang dibundel dengan Unity3D. Vuforia adalah sistem augmented reality berbasis penanda dan memungkinkan deteksi visi dan fungsionalitas pelacakan ke Unity3D IDE, juga memungkinkan pengembang untuk dengan mudah membuat aplikasi dan game AR [15].

Unity: Unity 3D adalah mesin pengembangan kaya terintegrasi yang kaya fitur yang menyediakan fungsionalitas out-of-the-box untuk pembuatan konten 3D interaktif. Menggunakan Unity, pengembang dapat menerbitkan ke berbagai platform seperti PC, Web, iOS, Android dan Xbox. Dalam tahap pengembangan mobile augmented reality, model 3D pertama dari perangkat keras komputer disiapkan. Kedua, spidol yang digunakan untuk memicu model 3D didaftarkan ke database di portal pengembang Vuforia seperti yang ditunjukkan pada Gambar 2.

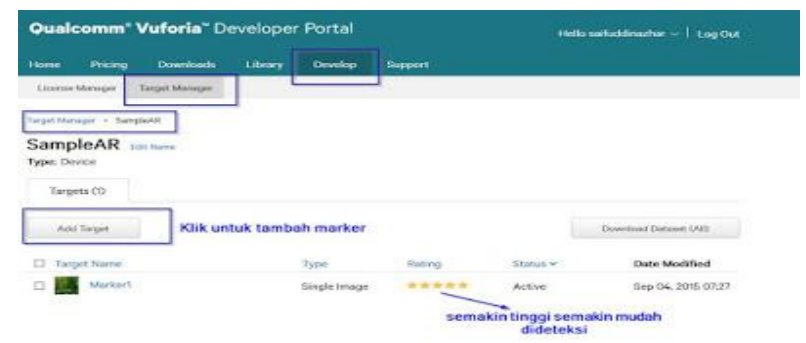

Gambar 2. Mendaftarkan marker di portal Pengembang Vuforia

Basis data ini kemudian diunduh dan diimpor ke Unity3D untuk menentukan marker. Ketiga, tata letak augmented reality dirancang seperti yang ditunjukkan pada Gambar 3.

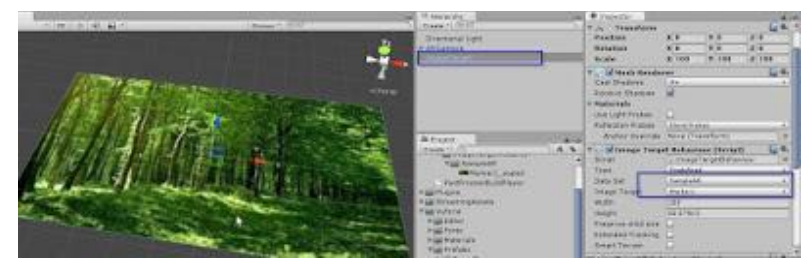

Gambar 3. Desain layout augmented reality

Layout yang terdiri dari teks, video dan model 3D dari potongan-potongan perangkat keras komputer ditempatkan di layar dan sudut-sudut kamera disiapkan sesuai. Untuk menampilkan teks dan memutar video pada saat yang sama, diperlukan pengodean di editor scripting.

\section{Pengumpulan data}

Pengembangan augmented reality diikuti oleh pertanyaan survei yang menyelidiki pendapat calon guru. Survei terdiri dari pilihan ganda, pertanyaan terbuka dan jenis skala yang dikembangkan oleh peneliti menggunakan tinjauan literatur yang relevan tentang augmented reality.

Pertanyaan deskriptif dasar tentang kepemilikan teknologi dan penggunaan augmented reality seluler diikuti oleh perasaan dan persepsi calon guru. Dalam penggunaan perangkat survei yang dilakukan, pengetahuan $\mathrm{AR}$, perasaan dan pendapat AR dikumpulkan dengan menggunakan pertanyaan jenis skala. Pertanyaan survei diberi peringkat dari 0-5 dan 1-5 yaitu (untuk tingkat pengetahuan; $0=$ tidak ada; 5 = sangat baik dan untuk perasaan / pendapat; 1 = sangat tidak setuju; 5 = sangat setuju).

Untuk mendapatkan validitas dan untuk menghindari ambiguitas, pertanyaan survei diperiksa oleh para ahli dalam bahasa dan teknologi pendidikan. Survei serta aplikasi diperiksa dalam konteks kegunaan, daya tarik dan dimensi kepuasan dengan bidang para ahli. Item jenis skala dikembangkan untuk mengukur dimensi kegunaan, daya tarik dan kepuasan disiapkan dalam cakupan ini. Untuk validitas konten, peneliti mengirim item jenis skala ke tiga ahli dan sesuai dengan rekomendasi mereka pertanyaan disusun ulang. Analisis reliabilitas dilakukan pada pendapat tentang skala nilai Teknologi AR yang terdiri dari 12 item. Cronbach's alpha menunjukkan bahwa pertanyaan jenis skala mencapai keandalan yang dapat diterima, $\alpha=0,892$.

Sebelum pengumpulan data, guru-guru diberi pelatihan selama 4 hari untuk mengembangakan media pembelajaran berbasis augmented reality.

\section{Analisis Data}

Setelah proses pengumpulan data, data kuantitatif dianalisis dengan statistik deskriptif di SPSS dan didapatkan hasil yang sesuai. Analisis statistik deskriptif dilakukan untuk mengidentifikasi tingkat kepuasan menggunakan aplikasi AR yang dikembangkan dalam media pembelajaran. Selain itu siberikan pertanyaan terbuka di mana guru mengungkapkan pendapat mereka tentang pengalaman AR untuk selanjutnya dianalisis dengan analisis konten. Proses dasar dalam analisis konten adalah untuk menyatukan data dalam kerangka konsep dan tema tertentu, dan untuk mengedit dan menafsirkannya. Selain itu, 
menurut [16] untuk memberikan validitas dan reliabilitas, perlu membuat deskripsi terperinci.

\section{Pengetahuan tentang teknologi AR}

Tingkat pengetahuan guru tentang AR. Sebagian besar guru tidak memiliki pengetahuan tentang teknologi AR. Ini diikuti dengan pengetahuan AR yang buruk hanya 1 orang dari 21 peserta yang telah mengetahui teknologi augmented reality. Tetapi untuk tingkat pengetahuan penggunaan perangkat seperti desktop, laptop, tablet, dan telepon pintar para guru sebagian besar sudah menggunakan dengan baik dan lebih dari 5 tahun.

Tabel 1. Instrumen Persepsi Peserta terhadap penggunaan Teknologi Augmented Reality untuk pengembangan media pembelajaran oleh guru - guru MGMP Bahasa Inggris Kab. 50 Kota

\begin{tabular}{lll}
\hline \multicolumn{1}{c}{ Pernyataan Peserta } & N & Rerata \\
\hline Teknologi AR terlihat menarik & 21 & 4,74 \\
Teknologi AR terlihat asli & 21 & 4,67 \\
teknologi AR terlihat berguna & 21 & 4,74 \\
teknologi AR terlihat memuaskan & 21 & 4,40 \\
Teknologi AR fleksibel & 21 & 4,54 \\
Saya pikir bahwa penggunaan AR & 21 & 4,44 \\
dapat meningkatkan keterampilan & & \\
spasial & & \\
Penggunaan teknologi AR dalam & 21 & 4,65 \\
pembelajaran tampak menarik & & \\
Saya percaya teknologi AR telah & 21 & 4,63 \\
meningkatkan motivasi belajar saya & & \\
Aplikasi AR menciptakan rasa & 21 & 4,39 \\
realitas & & \\
Saya ingin materi pembelajaran & 21 & 4,65 \\
didukung dengan AR & & \\
Saya ingin menggunakan aplikasi & 21 & 4,62 \\
AR dalam pembelajaran kami & & \\
Saya puas dengan aplikasi AR & 21 & 4,54 \\
(multimedia, gambar, suara, dll.) & & \\
\hline
\end{tabular}

Pendapat calon guru tentang AR diberikan pada Tabel 1 di atas. Menurut hasil, skor rata-rata calon guru memiliki skor rata-rata tertinggi 4,74 dalam opsi "teknologi AR terlihat menarik" dan "teknologi AR berguna". Di sisi lain, karena materi pengajaran sebagian besar terdiri dari video dan teks, guru-guru memberi nilai skor rata-rata paling rendah untuk opsi "aplikasi AR menciptakan rasa realitas" 4,39. Materi AR yang dikembangkan terdiri dari model 3D, teks dan elemen audio. Hasil ini mungkin karena bahan AR tidak sekaya yang diharapkan. Sebagian besar materi AR harus dirancang sedemikian rupa sehingga siswa dapat merasakan kenyataan. Untuk membangun rasa realitas yang tinggi, aplikasi yang lebih interaktif juga harus dibuat.

\section{KESIMPULAN}

Konten lebih mudah diakses daripada sebelumnya tetapi terbatas pada ruang fisik. Dengan menggunakan augmented reality, kita dapat melihat lingkungan kita berubah secara dinamis baik melalui smartphone atau kacamata untuk menampilkan konten dan media yang diletakkan tepat di depan kita; semakin banyak tersedia di ponsel dan perangkat portabel lainnya. Temuan dari penelitian ini menunjukkan kepada kita bahwa lebih banyak penelitian dan bahan pembelajaran harus dikembangkan oleh AR dan diimplementasikan dalam pembelajaran. Untuk mengembangkan AR terlebih dahulu, teknologi dan model 3D yang diperlukan harus disiapkan dan kerangka kerja juga harus dipertimbangkan.

Hasil survei ini menunjukkan kepada kita bahwa meskipun guru memiliki pengetahuan yang baik tentang smartphone dan komputer laptop, mereka memiliki pengetahuan yang sedikit tentang augmented reality. Sebagian besar guru memiliki pengetahuan tentang istilah tersebut tetapi tidak secara rinci tentang teknologi AR dan kemungkinan penggunaan dalam banyak pengaturan. Setelah menggunakan materi augmented reality, guru sangat bersemangat dan menyatakan bahwa augmented reality memiliki potensi besar digunakan dalam bahan ajar dan pembelajaran. Juga, mereka menyatakan bahwa mereka ingin melihat teknologi AR di lingkungan pembelajaran dan pembelajaran mereka.

Selanjutnya, augmented reality harus diintegrasikan dalam pengaturan pendidikan dan penelitian lebih lanjut harus dilakukan pada efektivitas bahan belajar mengajar yang dirancang dengan perangkat tambahan AR.

\section{DAFTAR PUSTAKA}

[1] Cuendet S., Bonnard Q., Do-Lenh S., Dillenbourg P. 2013, Designing augmented reality for the classroom, Computers \& Education, 68, 2013, pp. 557-569. 
[2] P. O'Shea et al., "Lessons Learned about Designing Augmented Realities," Int'l J. Gaming and Computer-Mediated Simulations, no. 1, vol. 1, 2008, pp. 1-15.

[3] Moro, C., Štromberga, Z., Raikos, A., \& Stirling, A, 2017, The effectiveness of virtual and augmented reality in health sciences and medical anatomy. American Association of Anatomists, vol. 10, no. 6, pp. 549-559. doi: 10.1002/ase. 1696

[4] Carrera, C. C., \& Asensio, L. A, 2017, Augmented reality as a digital teaching environment to develop spatial thinking. Cartography and Geographic Information Science, vol. 44, no. 3, pp. 259-270. doi: https://doi.org/10.1080/15230406.2016.1145 $\underline{556}$

[5] Lee, G. A., Dünser, A., Kim, S., \& Billinghurst, M., 2012, Cityviewar: A mobile outdoor ar application for city visualization. Mixed and Augmented Reality (ISMAR-AMH) 2012 IEEE International Symposium (pp. 5764). IEEE 2012

[6] Aebersold, M., Voepel-Lewis, T., Cherara, L., Weber, M., Khouri, C., Levine, R., \& Tait, A. R, 2018, Interactive Anatomy-Augmented Virtual Simulation Training. Clinical Simulation in Nursing, pp. 34-41.

[7] Serio, Á. D., Ibáñez, M. B., \& Kloos, C. D, 2013, Impact of an augmented reality system on students' motivation for a visual art course. Computers \& Education, 68, pp. 586-596.

[8] Moro, C., Štromberga, Z., Raikos, A., \& Stirling, A, 2017, The effectiveness of virtual and augmented reality in health sciences and medical anatomy. American Association of Anatomists, vol. 10, no. 6, pp. 549-559. doi:10.1002/ase.1696

[9] Chiang, T. H., Yang, S. J., \& Hwang, G.-J, 2014, An Augmented Reality - based Mobile Learning System to Improve Students' Learning Achievements and Motivations in Natural Science Inquiry Activities. Educational Technology \& Society, vol. 17, no. 4, pp. 352-365.

[10] Kaufmann, H., \& Schmalstieg, D, 2003, Mathematics and geometry education with collaborative augmented reality. Computers \& Graphics, vol. 27, no. 3, pp. 339-345.
[11] Chang, H.-Y., Wu, H.-K., \& Hsu, Y.-S, 2013, Integrating a mobile augmented reality activity to contextualize student learning of a socioscientific issue. British Journal of Education Technology, vol. 44, no. 3, pp. E95E99.

[12] Kucuk, S., Kapakin, S., \& Goktas, Y, 2016, Learning Anatomy via Mobile Augmented Reality: Effects on Achievement and Cognitive Load. Anatomical Sciences Education, vol. 9, no. 5, pp. 411-421. doi:10.1002/ase. 1603

[13] Schmidt, J, 2017, 8 Best augmented reality SDK for AR development for $\mathrm{iOS}$ and Android in 2017. Retrieved 02 06, 2018, from ThinkMobiles: https://thinkmobiles.com/blog/best-ar-sdkreview/

[14] Jackson, S. L, Research Methods and Statistics: A Critical Thinking Approach 3rd edition, CA: Wadsworth, Belmont, 2009.

[15] Santoso, M., \& Gook, L. B, 2012, ARkanoid: Development of 3D Game and Handheld Augmented Reality. International Journal Of Computational Engineering Research, vol. 2, no. 4, pp. 1053-1059.

[16] Yıldırım, A., \& Şimşek, H, Soysal Bilimlerde Nitel Araştırma Yöntemleri, Seçkin Yayıncılık, Ankara, 2013. 